Jarosław Horowski

Uniwersytet Mikołaja Kopernika w Toruniu

\title{
WSTYD A ROZWÓJ MORALNY - O ANTROPOLOGICZNYCH FUNDAMENTACH NEOTOMISTYCZNEJ TEORII WYCHOWANIA MORALNEGO
}

The sense of shame and moral development - about the anthropological foundations of the neo-Thomistic theory of moral education

Summary: Shame is an unpleasant feeling man tries to avoid. However, representatives of neo-Thomistic education philosophy perceive shame as an important factor for moral development. The article presents the reflections of representatives of Neo-Thomism, i.e. Jack Woroniecki and Karol Wojtyla, on the role of shame in moral development. They relate shame to activities driven by the senses rather than by the intellect and reason. This is because the senses react to material good and the intellect recognizes moral good. Therefore, shame induces rational actions and at the same time induces acts which take into account moral good. Furthermore, shame warns against the threat of human dignity violation and therefore helps discover the value of human life. Thus, foundations for moral standards are created. The article presents philosophical and ethical assumptions of neo-Thomism; the interpretation of shame within the Neo-Thomism framework. The article also draws conclusions for educational theory and educational practice based upon the study of shame.

Keywords: shame, moral development, neo-Thomistic education philosophy, development of rational actions, discovering the value of human life

Pierwsze skojarzenia, jakie wywołuje słowo „wstyd”, odnoszą się zazwyczaj do jego objawów, a te nie są dla człowieka przyjemne: zaburzenia mowy, opuszczona głowa, odwracanie wzroku, rumieńce, używanie unikowych określeń siebie ${ }^{1}$. Wstyd jest bowiem rodzajem złości skierowanej na samego siebie - jest to złość wywołana

\footnotetext{
${ }^{1}$ Theodore D. Kemper, „Modele społeczne w wyjaśnianiu emocji”, przekł. Piotr Kołyszko, w: Psychologia emocji, red. Michael Lewis, Jeannette M. Haviland-Jones (Gdańsk: Gdańskie Wydawnictwo Psychologiczne, 2005), 79 .
} 
błędem albo niepotrzebnym zachowaniem², stan dla człowieka szczególnie przykry, gdy niewłaściwe działanie miało miejsce na oczach innych ludzi. Nie powinno zatem dziwić, że człowiek chciałby uniknąć wstydu, tym bardziej, że uczucia nie występują zazwyczaj $\mathrm{w}$ formie wyizolowanej, a wraz ze wstydem może pojawić się niska samoocena, lęk o relacje międzyludzkie, o akceptację ze strony innego człowieka3. Owa „ucieczka od wstydu” może przybierać różną postać: unikania pochopnego podejmowania decyzji, tak aby wyeliminować niebezpieczeństwo błędu, ukrywania złego działania przed innymi ludźmi. Jednak może to być także dążenie do dekonstrukcji czynników, którymi uwarunkowane jest poczucie wstydu, a do nich należą z pewnością normy moralne będące kryterium oceny dla własnego sumienia oraz punktem odniesienia dla grupy, w której funkcjonuje jednostka4.

W kontekście przywołanych powyżej faktów związanych z rzeczywistością wstydu odpowiedź na pytanie zasugerowane w tytule artykułu - o wpływ wstydu na rozwój moralny człowieka - wydaje się oczywista. Wstyd jawi się jako czynnik wpływający negatywnie na ów rozwój, tymczasem w tekstach przedstawicieli neotomistycznej filozofii wychowania uznawany jest on za czynnik wspierający rozwój moralny. Spośród polskich przedstawicieli tego nurtu temat wstydu podejmują przede wszystkim Jacek Woroniecki i Karol Wojtyła, wspomina o nim również Karol Górski5. Ich stanowisko ma fundament przede wszystkim w poglądach Tomasza z Akwinu, który istotę wstydu rozważa w Sumie teologicznej, w części poświęconej cnocie umiarkowania (II-II, q. 144) ${ }^{6}$. Inspiracją dla Karola Wojtyły jest także fenomenologia Maxa Schelera7, który poświęcił wstydowi obszerny traktat ${ }^{8}$,

${ }^{2}$ Dariusz Doliński, „Ekspresja emocji. Emocje podstawowe i pochodne”, w: Psychologia. Podręcznik akademicki, t. 2: Psychologia ogólna, red. Jan Strelau (Gdańsk: Gdańskie Wydawnictwo Psychologiczne, 2000), 366.

${ }^{3}$ Michael Lewis, „Emocje samoświadomościowe: zażenowanie, duma, wstyd, poczucie winy”, przekł. Ewa Wojtych, w: Psychologia emocji, dz. cyt., 787.

${ }^{4} \mathrm{~W}$ psychoanalizie wstyd uważa się za emocję destrukcyjną, hamującą ekspresję seksualną, twierdzi ona ponadto, że wyparty ze świadomości i utrzymujący się w podświadomości wstyd może powodować niepokój, histerię i neurastenię (Agata Błachnio, „Wstyd. Aspekt psychologiczny”, w: Encyklopedia katolicka, t. XX, red. Edward Gigilewicz i in. [Lublin: Towarzystwo Naukowe KUL, 2014], kol. 1011). W efekcie teorie społeczno-kulturowe, uwzględniające tezy psychoanalizy, będą zawierały postulat dekonstrukcji norm piętnujących niektóre formy aktywności seksualnej (normy występują tutaj w roli Superego, por. Krystyna Drat-Ruszczak, „Teorie osobowości - podejście psychodynamiczne i humanistyczne”, w: Psychologia. Podręcznik , t. 2, 614) i przyczyniających się do powstawania wstydu u osób je podejmujących. Owe formy aktywności seksualnej nazywane będa , „innymi”, , ,alternatywnymi” bez przypisywani im wartości moralnej.

${ }^{5}$ Myśl neotomistyczna w Polsce posiada bogatą tradycję, jak można przekonać się z opracowania Janiny Kostkiewicz (tejże, Kierunki i koncepcje pedagogiki katolickiejw Polsce 1918-1939 [Kraków: „Impuls”, 2013], 87-190), jednak bezpośrednie odniesienia do wstydu znajdujemy przede wszystkim w pracach Jacka Woronieckiego i Karola Wojtyły.

${ }^{6}$ Tomasz z Akwinu, Suma teologiczna, t. 22: Umiarkowanie, przekł. Stanisław Bełch (Londyn: Katolicki Ośrodek Wydawniczy „Veritas” 1966), 40-50.

${ }^{7}$ Mirosław Mróz, „De verecundia, czyli o kwestii wstydu widzianej oczyma św. Tomasza z Akwinu”, w: Wstyd i nagość, red. Marian Grabowski (Toruń: Wydawnictwo Uniwersytetu Mikołaja Kopernika 2003), 180-181.

${ }^{8}$ Wydanie polskie: Max Scheler, „O wstydzie i poczuciu wstydu”, przekł. Marzena Świtalska, w: Wstyd i nagość, red. Marian Grabowski (Toruń: Wydawnictwo Uniwersytetu Mikołaja Kopernika 2003), 19-142. 
przy czym Wojtyła nie zatrzymał się w swoich analizach na opisie fenomenologicznym wstydu, ale dokonał jego interpretacji metafizycznej.

Rozważania, które zostaną podjęte w niniejszym tekście, będą miały na celu odpowiedź na pytanie o rolę, jaką neotomiści przypisywali wstydowi w procesie rozwoju moralnego. Badania rozpoczęte zostaną od skrótowej charakterystyki wstydu, co pozwoli w dalszej części pracy dostrzec specyfikę jego ujęcia ze strony neotomistów. W kolejnym punkcie przybliżone zostaną poglądy Jacka Woronieckiego i Karola Wojtyły na temat wstydu, a następnie filozoficzno-etyczne założenia ich koncepcji. W ostatniej części podjęta zostanie próba odpowiedzi na pytanie o pedagogiczne implikacje wyników badań nad wstydem, jakie przeprowadzone zostały w ramach filozofii neotomistycznej.

\section{Czym jest wstyd?}

Pojęcie „wstyd” wykorzystywane jest do opisu przynajmniej trzech rzeczywistości, które, choć przejawiają się na zewnątrz w podobnych reakcjach, nie są tożsame jeżeli chodzi o ich przyczyny. Po pierwsze, terminu „wstyd” używa się na określenie swoistej reakcji ostrzegawczej przed możliwością naruszenia ludzkiej godności, miłości i intymności przez innego człowieka, zagrożeniem instrumentalnego przez niego wykorzystania. W ramach tego rodzaju wstydu mieści się także wstyd seksualny. Po drugie, wstyd może wynikać z negatywnej oceny własnego zachowania. W tym sensie ujawnia istnienie jakiegoś kryterium dobrego i złego zachowania, odzwierciedla jakiś etos, a nawet go chroni, wskazując i piętnując zachowania z nim sprzeczne9. Po trzecie, człowiek wstydzi się tych swoich zachowań, w których traci kontrolę nad emocjami, a więc nie wynikają one z rozumnej decyzji.

Nietrudno zauważyć, że wstyd w pierwszym sensie istotnie różni się od wstydu w drugim i trzecim znaczeniu, ponieważ jako reakcja ostrzegawcza wobec zagrożenia naruszenia godności nie powstaje w konsekwencji aktywności podmiotu, ale innej osoby, natomiast przyczyną wstydu w drugim i trzecim sensie jest działanie jednostki. Zauważyć również należy, że drugi i trzeci rodzaj wstydu są sobie bliskie, ale nie tożsame. Działanie rozumne ujawnia się z jednej strony w podporządkowaniu normom, etosowi (co wskazywałoby na tożsamość), ale z drugiej strony możliwy jest także rozumny wybór, który wywoła wstyd ze względu na świadomość jego nieakceptacji przez społeczność, do której należy jednostka ${ }^{10}$. Ów wstyd może wówczas łączyć się z przekonaniem, że podjęte działanie zostanie niewłaściwie zinterpretowane przez inne osoby ${ }^{11}$.

W tym kontekście należałoby zwrócić również uwagę na kwestię źródła etosu, który staje się punktem odniesienia dla wstydu - czy wywodzi się on ze społeczności, w której żyje jednostka, czy ma podstawy w naturze człowieka, czy może pochodzi od

\footnotetext{
${ }^{9}$ Tadeusz Zadykowicz, „Wstyd. Aspekt moralny”, w: Encyklopedia katolicka, t. XX, kol. 1010.

${ }^{10}$ Błachnio, „Wstyd, 1011.

${ }^{11}$ Zadykowicz, „Wstyd, 2010.
} 
jakiejś siły wyższej? Postawione tu pytanie nie znajduje jednoznacznej odpowiedzi z przynajmniej dwóch względów: po pierwsze, zmienia się ona wraz z założeniami filozoficzno-światopoglądowymi, w ramach których jest udzielana; po drugie, wskazane czynniki w konkretnych przypadkach łączą się ze sobą, czyli zakorzenione w naturze prawidłowości wzmacniane są przez kulturę grupy odniesienia albo przez objawienie zawarte $\mathrm{w}$ wyznawanej religii. Trudności wodpowiedzi na pytanie o źródło etosu nie uniemożliwiają jednak stwierdzenia, w jaki sposób założenia filozoficzno-światopoglądowe zmieniają interpretację wstydu. Wskazówki do rozwiązania tej kwestii sformułowane zostaną w dalszej części tekstu.

Wśród neotomistów na temat wstydu wypowiadali się przede wszystkim Jacek Woroniecki oraz Karol Wojtyła. Wspominał również o nim Karol Górski. Przyjrzyjmy się zatem ich wypowiedziom, aby stwierdzić, o jakiej rzeczywistości mówili, używając terminu „wstyd”.

\section{Wstyd jako konsekwencja własnego zachowania}

Uwzględniając perspektywę chronologiczną, jako pierwszy na temat pozytywnej roli wstydu w rozwoju moralnym wypowiedział się Jacek Woroniecki. Jego badania nad rozwojem moralnym koncentrowały się na powstawaniu stałej sprawności do wykonywania określnych czynów. Woroniecki rozumiał, że zdobycie owej sprawności jest konsekwencją rozwoju nie tyle jednej władzy, co wszystkich władz zaangażowanych w czyn. Ukształtowanie pozytywnego profilu moralnego wymagało zatem odpowiedniego rozwoju rozumu, woli oraz władz zmysłowych: pożądliwej i popędliwej, które powinny przyjąć doskonałość cnót kardynalnych: roztropności, sprawiedliwości, umiarkowania i męstwa.

Zaznaczyć należy, że Woroniecki wyraźnie odróżniał sprawności od nawyków, co w kategoriach współczesnej pedagogiki oznaczałoby, że opowiadał się za wychowaniem człowieka autonomicznego, zdolnego do podejmowania samodzielnych, będących konsekwencją rozumnego osądu decyzji. Krytyce poddawał natomiast urabianie czy tresurę, które prowadziły do nawyku mechanicznego, bezrefleksyjnego powtarzania tych samych zachowań. Innymi słowy, Woroniecki rozumiał wychowanie jako proces, w którym władze bezpośrednio odpowiedzialne za pożądanie „uczą się" słuchać rozumu i współdziałać z nim w celu osiągnięcia dobra. Dobór słów i zwrotów w celu wyrażenia myśli Woronieckiego jest w tym wypadku niezwykle ważny. Woroniecki nie nazwałby bowiem dobrze wychowanym kogoś, kto „panuje” nad zmysłami, to znaczy w jakiś sposób powstrzymuje ich reakcje. Za człowieka dobrze wychowanego uznałby jedynie taką osobę, której zmysły „doceniają" mądrość rozumu i współdziałają z nim, wykorzystując potencjal tkwiący w ciele. Pierwsza z cnót doskonalących zmysły, czyli umiarkowanie, nie polega bowiem na rezygnacji z zaspokajania pożądań zmysłowych, ale na takim korzystaniu 
z dóbr zmysłowych, które jest mądre/roztropne, czyli skoordynowane z dążeniem do dobra zaspokajającego pragnienie szczęścia ${ }^{12}$.

W tym kontekście zasadne wydaje się pytanie o możliwości pracy nad zmysłami. Odpowiadając na nie, Woroniecki wyraża przekonanie, że fundamentalną rolę odgrywają w tym procesie poczucie godności oraz wstyd. Te dwie rzeczywistości odnoszą się do jednego fundamentu, jakim jest rozumność ludzkiej natury. Poczucie godności jest bowiem konsekwencją świadomości owej rozumności, czyli zdawania sobie sprawy przez jednostkę, że posiada rozum, za pomocą którego na zupełnie innym niż zwierzęta poziomie jest w stanie rozpoznawać dobro i zło czynów, a w konsekwencji także - transcendując niejako cielesne pożądania - jest w stanie podejmować rozumne decyzje ${ }^{13}$. Poczucie wstydu jest $\mathrm{z}$ kolei rozumiane przez Woronieckiego jako reakcja na czynności, które nie znajdują źródła w rozumie, ale w nieuporządkowanych pożądaniach, uderzając wludzką godność. Jak pisze: „człowiek najbardziej wstydzi się tych czynności, w których bardziej niż w innych przestaje kierować się rozumem" i dla lepszego zobrazowania tej prawidłowości dodaje: „[m]a to nawet miejsce w stosunku małżeńskim” ${ }^{14}$. Woroniecki pisze ponadto o wstydzie w konsekwencji zablokowania rozumu pod wpływem silnego gniewu oraz w sytuacji pijaństwa. Wstyd - według niego - stanowi zatem „ochronę władz umysłowych, rozumu i woli, przed opanowaniem ich przez władze zmysłowe. Jest to jakby samorzutna ochrona godności ludzkiej przed obniżeniem jej do poziomu zwierząt"

W swoich rozważaniach Woroniecki nie do końca jednak odróżnia czynniki wewnętrzne oraz zewnętrzne warunkujące odruch wstydu. W prowadzonej przez dominikanina narracji przeplatają się one ze sobą. Pisze on chociażby o wstydzie: „Jest to swego rodzaju obawa towarzysząca czynnościom mogącym - o ile się nie rachują z godnością ludzką - zniesławić człowieka w oczach innych"16. Trudno zaprzeczyć w tym wypadku występowaniu zarówno jednych, jak i drugich, jednak dla jasności przekazu konieczne wydaje się ich odróżnienie. Odruch wstydu może faktycznie być związany z działaniem, w którym podmiot traci kontrolę nad sobą, ale podobnej reakcji można doświadczyć z związku z podejmowaniem działań nieakceptowanych przez otoczenie, chociaż są one rozumne i dobre. Odruch wstydu

12 Szczegółową analizę teorii Woronieckiego odnaleźć można wnastępujących pracach: Stanisław Gałkowski, Ku dobru. Aktualność filozofii wychowania Jacka Woronieckiego (Rzeszów: Wydawnictwo WSP 1998); Jarosław Horowski, Wychowanie moralne wedhug pedagogiki neotomistycznej (Toruń: Wydawnictwo UMK 2015), 142-187.

${ }^{13}$ Jacek Woroniecki, Katolicka etyka wychowawcza, t. II/1 (Lublin: Redakcja Wydawnictw KUL, 2000), 337; Jacek Woroniecki, „Cnota kardynalna umiarkowania”. Szkoła Chrystusowa I/5 (1930): 236-237.

${ }^{14}$ Woroniecki, Katolicka, t. II/1, 339; Woroniecki, „Cnota”, 234-236.

${ }^{15}$ Woroniecki, Katolicka, t. II/1, 340. Woroniecki uważa, że rozum i wola mogą tak wpływać na uczucia, aby te osłabły, gdyby ich dążenia były sprzeczne ze sposobem działania wyznaczanym przez rozum, a równocześnie mogą wykorzystywać ich siłę do realizacji dobra wskazanego przezeń. Jako przykład wychowania uczuć Woroniecki podaje cnotę łagodności, która rodzi się na fundamencie zrozumienia, że gniew jest cenną siłą, którą trzeba sprawnie władać i nie marnować jej ani na drobne złoszczenie się ani na większe, niegodne człowieka wybuchy (tamże, 392).

${ }^{16}$ Tamże, 339. 
może pojawiać się na przykład w związku z podejmowaniem praktyk religijnych, które w pewnych środowiskach mogą być wyśmiewane. W tym drugim przypadku wpływ społeczności na jednostkę należałoby ocenić jako negatywny, a w pismach Woronieckiego społeczność jest określana jednoznacznie pozytywnie jako czynnik wzmacniający ochronę godności poprzez wstyd.

Myśl Woronieckiego podejmuje Karol Górski, który w swoich pracach deklaruje z jednej strony nawiązania do tomizmu egzystencjalnego Jacques'a Maritaina, a z drugiej strony, prowadząc wywód, rozkłada akcenty w sposób charakterystyczny dla tomizmu tradycyjnego, którego przedstawicielem jest Woroniecki. W podstawowej pracy pedagogicznej Górskiego pod tytułem Wychowanie personalistyczne odnajdujemy następujące zdanie: „wstyd płynie z faktu, że człowiek nie umie opanować odruchów instynktu. Jest to niezmiernie dla intelektu upokarzające, iż on, widząc rzeczy tak, jak one są, nie ma pełnej władzy nawet nad własnem ciałem, które czasem wyłamuje się spod jego kontroli. To upokorzenie jest równocześnie potężną dźwignią postępu osobowości, wskazuje bowiem i przypomina nieustannie potrzebę pracy nad sobą"17. Z przytoczonych słów wynikają zarówno kojarzenie objawów nazywanych wstydem z procesami wewnątrzosobowymi, jak również pozytywna ocena roli wstydu jako czynnika w rozwoju moralnym. W pracach Górskiego nie odnajdujemy jednak pogłębionej refleksji, mogącej rzucić światło na rzeczywistość wstydu. Tę przeprowadził dopiero Karol Wojtyła.

Badania Wojtyły nie posiadają wyraźnie pedagogicznego profilu, jednak trudno nie dostrzec ich potencjału, biorąc pod uwagę, że istotą jest wyjaśnianie procesów wewnątrzpodmiotowych: Wojtyła analizuje czyn, wkonsekwencji odsłaniając osobę. Czego dowiadujemy się z tych analiz? Refleksja antropologiczna prowadzi do wniosku, że człowiek z jednej strony odpowiada na rzeczywistość, czyli zewnętrzny względem podmiotu przedmiot wywołuje w nim reakcję dzięki tkwiącej w podmiocie strukturze psychoemotywnej, a z drugiej strony odróżnia to, co w podmiocie tylko „dzieje się” od aktów, które w nim znajdują swą przyczynę. Odkrywając różnicę między uczynnieniem (zdynamizowaniem struktury psychoemotywnej) a czynem, człowiek odkrywa równocześnie specyfikę własnej natury, która wyraża się w sprawczości. Co więcej, zdaje sobie sprawę, że jego powinnością staje się działanie rozumne, wynikające z decyzji. Ta prawidłowość została doskonale oddana przez Wojtyłę, gdy pisal, że człowiek: „odnajduje swoje «ja» jako tego, który [...] może i powinien siebie posiadać i sobie panować. Dynamiczna struktura samostanowienia mówi człowiekowi za każdym razem o tym, że jest sobie samemu dany i zadany równocześnie. Właśnie w ten sposób człowiek jawi się sobie samemu w swoich czynach, w wewnętrznych rozstrzygnięciach sumienia"18. Zadaniem człowiek jest zatem aktualizacja własnego bytu na poziomie osoby. Jej

\footnotetext{
${ }^{17}$ Karol Górski, Wychowanie personalistyczne (Poznań: Naczelny Instytut Akcji Katolickiej 1936), 35.

${ }^{18}$ Karol Wojtyła, „Podmiotowość i «to, co nieredukowalne»”, w: tegoż, Osoba i czyn oraz inne studia antropologiczne (Lublin: Towarzystwo Naukowe KUL, 1994), 441; tegoż, Transcendencja osoby w czynie a autoteleologia człowieka, w: tamże, 485-488.
} 
przeciwieństwem jest aktualizacja na poziomie psychoemotywnym, czyli na tym, w którym o działaniu decydują zmysły.

Odkrycie specyfiki własnej natury oraz istniejącej wobec niej powinności prowadzi z kolei - według Wojtyły - do odruchu wstydu w sytuacji, gdy owa powinność nie została zrealizowana. Jak pisze w studium Miłość $i$ odpowiedzialność: „Człowiek z reguły wstydzi się tego, co w nim tylko «dzieje się», a co nie jest świadomym aktem jego woli, tak więc np. wstydzi się wybuchów namiętności, choćby gniewu czy strachu [...]. Znajdujemy w tym potwierdzenie duchowości i «wewnętrzności» osoby ludzkiej, która dostrzega pewne «zło» w tym wszystkim, co nie jest dosyć wewnętrzne, czyli duchowe, ale tylko zewnętrzne, cielesne, irracjonalne"19. Warto ponadto zauważyć, że z analiz Wojtyły, przeprowadzonych w studium Osoba i czyn, wynika, że pierwsze wnioski odnośnie jakości działania wyciągane są przez podmiot nie po jego wykonaniu, ale już w trakcie podejmowania decyzji. Dzięki świadomości podmiot odkrywa bowiem, które z pożądań jest konsekwencją działania dynamizmu psychoemotywnego (czyli władz zmysłowych), a które jest odpowiedzią woli na wskazania rozumu, czyli jest przejawem osobowej sprawczości. Wstyd może zatem przenikać ludzkie działanie, a nie tylko pojawiać się jako jego konsekwencja. Dochodzimy w tym miejscu do kwestii niezwykle istotnej z punktu widzenia rozwoju moralnego: czynnikiem o nim decydującym okazuje się odkrycie własnej duchowej natury oraz wstyd związany z działaniem na innym niż osobowy poziomie.

Podsumowując wyniki analiz fragmentów prac Woronieckiego, Górskiego i Wojtyły na temat wstydu, trudno nie zauważyć, że są oni zgodni co do istoty oraz znaczenia wstydu, odnosząc się do trzeciego znaczenia tego terminu. Uznać zatem należy, że to Woroniecki wprowadził zagadnienie wstydu do neotomistycznej filozofii wychowania. Równocześnie z przytoczonych stwierdzeń wynika, że Górski, a zwłaszcza Wojtyła, mówiąc o wstydzie, skupiają się na jego wewnątrzpodmiotowych przyczynach, ignorując równocześnie czynniki zewnętrzne, które mogą go stymulować. W ich pismach znajdujemy zatem doprecyzowanie analiz Woronieckiego, w których brak jest wyraźnego rozróżnienia między drugim i trzecim sensem określenia „wstyd”.

Przeprowadzone powyżej rozważania nawiązywały do fragmentów prac Woronieckiego i Wojtyły, w których wstyd lączony był z decyzjami podejmowanymi przez podmiot. Wojtyła zastanawia się jednak nad wstydem także winnym kontekście, odnosząc się do sytuacji, w której osoba przeżywająca wstyd pozostaje niejako bierna. Jest to zatem pierwsze ze wspomnianych w niniejszej pracy znaczeń tego terminu. Refleksję tę Wojtyła podejmuje w ramach prac nad etyką seksualną. Przyjrzyjmy się zatem, jakie wnioski na temat wstydu wyciąga z tych badań i jakie światło rzucają one na problem rozwoju oraz wychowania moralnego.

\section{Wstyd jako ochrona przed naruszeniem własnej godności}

Pisząc o wstydzie seksualnym, Wojtyła stwierdza, że nie wynika on z kultury, w jakiej żyje i rozwija się jednostka. Wstyd zakorzeniony jest głęboko w ludzkiej naturze, a jego istotą jest dążenie „do ukrycia samych wartości seksualnych, i to przede

\footnotetext{
${ }^{19}$ Tegoż, Miłość i odpowiedzialność (Lublin: Towarzystwo Naukowe KUL 1986), 162.
} 
wszystkim o tyle, o ile w świadomości danej osoby stanowią one «możliwy przedmiot użycia» dla osób drugiej płci”" ${ }^{20}$. Kultura wyznacza oczywiście - chociażby ze względu na klimat - pewne kanony ubioru, obnażania lub zakrywania poszczególnych części ciała, ale źródłem dążenia do ukrycia określonych części oraz niektórych, szczególnie intymnych, czynności cielesnych jest według niego przede wszystkim ochrona wartości własnej osoby. Wstyd seksualny nie jest zatem narzucony z zewnątrz, ale stanowi wewnętrzną potrzebę osobowości.

Zdaniem Wojtyły we wstydzie ujawnia się to, że osoba jest kimś więcej, niż tylko jej właściwości seksualne. Jak pisze: „[w]styd seksualny jest poniekąd objawieniem ponad-użytkowego charakteru osoby, i to zarówno wtedy, gdy osoba [...] wstydzi się związanych z jej ciałem wartości seksualnych, jak i wówczas, kiedy wstydzi się [...] swego stosunku do tych wartości u osób drugiej płci, swego nastawienia na samo ich użycie"21. Dzięki wstydowi osoba odkrywa (nawet jeżeli nie potrafi tego nazwać, wyrazić słowami), że „jest panią samej siebie (sui iuris) [...]. Jest własnością samej siebie, ma władzę samostanowienia, nikt nie może naruszać tej samoistności. Nikt też nie może uczynić jej swoją własnością [...]. Otóż ta obiektywna niedostępność (ateri incommunicabilitas) oraz nietykalność osoby dochodzi do głosu właśnie w przeżyciu wstydu seksualnego" 22 . W przytoczonych słowach Wojtyła wychodzi poza opis fenomenologiczny i dokonuje interpretacji metafizycznej wstydu.

Przyglądając się przywołanym stwierdzeniom, można by powiedzieć, że wstyd oraz to, co on odkrywa, czyli specyfika ludzkiego bytu i związana z nim godność, stają się punktem odniesienia dla moralności. To między innymi dzięki wstydowi człowiek poznaje kryterium dobra i zła, związane $\mathrm{z}$ afirmacją albo naruszeniem ludzkiej godności poprzez czyn. Jest to poznanie bezpośrednie, niezwiązane z przekazem poprzez kulturę, a w dodatku - niezbędne z perspektywy rozwoju moralnego, biorąc pod uwagę, że jest on rozwojem istoty rozumnej, a więc łączy się w pierwszym rzędzie $\mathrm{z}$ rozwojem intelektu (choć do niego się nie ogranicza).

Analizowane powyżej poznanie kryterium dobra i zła za sprawą przeżycia wstydu zawiera jednak pewną trudność. Wstyd jako sposób ochrony własnej osobowości ujawnia przed człowiekiem jego własną wewnętrzność, wyjątkowość, godność. Równocześnie drugi człowiek pozostaje dla podmiotu przedmiotem, doświadczany jest jako coś zewnętrznego, tak jak rośliny czy zwierzęta ${ }^{23}$. Aby bezpośrednie poznanie własnej wewnętrzności prowadziło do zrozumienia, że drugi jest ukonstytuowany tak samo jak ja, czyli do odkrycia, że on także posiada własną wewnętrzność, a nie jest jedynie kompilacją zewnętrznych cech, atrakcyjnych ze względu na ich wartości (na przykład seksualne), konieczna jest refleksja teoretyczna podmiotu ${ }^{24}$.

\footnotetext{
${ }^{20}$ Tamże, 158 .

${ }^{21}$ Tamże, 159-16o.

22 Tamże, 159.

${ }^{23}$ Karol Wojtyła, „Osoba i czyn”, w: Osoba, 53-56.

${ }^{24}$ Tegoż, „Uczestnictwo czy alienacja?”, w: Osoba, 448-451.
} 
Podjęty przez Wojtyłę namysł nad wstydem odsłania nie tylko jego istotę, ale także dostarcza wskazówek do głębszego poznania rozwoju moralnego jednostki, który uwarunkowany jest odkryciem godności człowieka. Spróbujmy teraz przyjrzeć się filozoficzno-etycznym założeniom przedstawionych powyżej interpretacji wstydu.

\section{Filozoficzno-etyczny kontekst neotomistycznej refleksji nad wstydem}

Przywołując neotomistyczne stwierdzenia na temat wstydu, trudno nie zauważyć ich filozoficzno-etycznych fundamentów. Są to z jednej strony tezy antropologiczne, według których człowiek posiada określoną naturę - nie tylko cielesną, ale i duchową, a z drugiej strony tezy dotyczące zewnętrznej względem człowieka rzeczywistości, która - według neotomistów - jest także określona i pośrednio staje się kryterium dobra oraz zła moralnego. Zatrzymajmy się nad tymi tezami.

Po pierwsze, z przywołanych fragmentów wynika, że człowiek jest kimś wyjątkowym, kimś innym niż pozostałe istoty żywe, ponieważ działa nie tylko na poziomie zmysłowym, ale posiada także wymiar duchowy z jego władzami: rozumem i wolą. Co więcej, jest świadomy tego wymiaru i dlatego próbuje go chronić zarówno we własnych działaniach, jak i przez ochronę własnego bytu przed ewentualnym wykorzystaniem ze strony innych osób.

Po drugie, przytoczoną powyżej interpretację wstydu przenika teza, że istnieje prawda/dobro, które nie posiada charakteru czysto materialnego i dlatego może stać się treścią rozumu, a równocześnie być „niewidoczne” dla zmysłów. Innymi słowy, człowiek zmysłowo odkrywa dobro materialne, które wywołuje reakcje w sferze psychoemotywnej, ale równocześnie dzięki rozumowi i jego zdolności do szerszego ujmowania konsekwencji poszczególnych działań jest wstanie określić prawdę i dobro niedostępne dla zmysłów.

Po trzecie, decyzja o wyborze dobra zmysłowego i zignorowaniu dobra rozumnego lub o rezygnacji z dobra zmysłowego na rzecz dobra rozumnego (przy założeniu, że między ich realizacją występuje konflikt) określana jest jako decyzja moralna. To, na jakim poziomie człowiek zaktualizuje swój byt - czy na poziomie osobowym, czy, przeciwnie, upodobni się do zwierząt - jest zatem pochodną i znajduje wyraz w moralności. W badaniach nad czynem Wojtyła oddzielił wprawdzie dla potrzeb analizy aspekt osobowy czynu od jego aspektu moralnego (w sposób analogiczny do matematycznego zabiegu wyciągnięcia liczby przed nawias), ale owo logiczne oddzielenie nie oznacza, że w praktyce owe aspekty nie przenikają się. Świadczą o tym słowa zamieszczone w studium Osoba i czyn: „Aksjologicznie [...] owo spełnienie jest spełnieniem tylko przez dobro, przez zło moralne natomiast jest poniekąd nie-spelnieniem. [...] Wartości moralne są tak istotne dla osoby, że prawdziwe jej spełnienie dokonuje się nie tyle przez sam czyn, ile przez moralną dobroć tego czynu" 25 . Bez aspektu moralnego podejmowanych decyzji nie można by

\footnotetext{
${ }^{25}$ Wojtyła, „Osoba”, 97.
} 
zatem mówić ani o aktualizacji człowieka na różnych poziomach ani o wstydzie, który wskazuje na integrację ludzkiej natury na poziomie innym niż umysłowy.

Po czwarte, filozofia tomistyczna zbudowana jest na założeniu realizmu ontologicznego, co prowadzi do interesujących tez w zakresie etyki. Obrazują to słowa Wojtyły, który sformułował następujący wniosek ze swoich badań: „Moralność jest jakąśs «rzeczywistością». Nie jest tylko czymś pomyślanym, jakąś «ideą», jakimś «a priori» - ale jest czymś rzeczywistym w człowieku i pomiędzy ludźmi, w społeczeństwie i pomiędzy społeczeństwami” ${ }^{26}$. W niniejszym cytacie przywoływane są opozycyjne stanowiska w kwestii pochodzenia moralności. Według pierwszego moralność jest czymś „pomyślanym”, jakimś konstruktem intelektualnym, według drugiego określoną rzeczywistością. Badania Wojtyły skłaniają do opowiedzenia się za drugą opcją. Potwierdzają to słowa: „u podstaw całego systemu norm [...] można by postawić taką zasadę: w całym twoim działaniu pozostawaj w zgodzie z obiektywną rzeczywistością" 2 . Nietrudno znaleźć podobne sformułowania u Woronieckiego i innych neotomistów. Woroniecki, mówiąc o fundamentach moralności, wskazuje na prawo naturalne i uprawnienia przyrodzone człowieka do: pożywienia, okrycia, niewyrządzania ciału niczego, co narażałoby je na śmierć lub kalectwo, wolności, poznania prawdy, dobrego imienia, własności ${ }^{28}$. Jego zdaniem, norm „sami nie wytwarzamy sobie, lecz [...] poznajemy je jako coś, co jest nam dane w naszej naturze, i czego [...] nie wolno nam zmieniać wedle naszej woli: to znów nas chroni od niedomagań moralności autonomicznej, od nadużyć indywidualizmu, egoizmu i od anarchii moralnej"29.

$\mathrm{Z}$ perspektywy analizowanego przez nas problemu jest to fundamentalne stwierdzenie. Gdyby normy moralne były jedynie czymś pomyślanym, gdyby decydował o nich człowiek, wówczas wstyd traciłby sens i zyskiwałby inną interpretację. Gdyby moralność była czymś subiektywnym, to każda opcja działania w danej sytuacji byłaby jednakowo dobra, a konkretna jednostka miałaby prawo do jej wyboru. Skąd zatem brałby się wstyd w konsekwencji podjęcia określonych działań? W tym kontekście można by tłumaczyć go na przykład wpływem norm uznanych w danym społeczeństwie i przekazywanych poprzez kulturę. Stanowityby one czynnik ograniczający człowieka, odbierający mu wolność. Drogą do pełnej wolności byłaby z kolei dekonstrukcja kultury. Uznanie, że rzeczywistość jest czymś realnym i implikuje obiektywną aksjologię, tworzy zatem punkt odniesienia dla interpretacji wstydu jako konsekwencji działania nierozumnego, to znaczy niewynikającego z rozumnej oceny rzeczywistości - działania, w którym podmiot w pewnym sensie stracił kontrolę nad sobą, pozwalając uzewnętrznić się w działaniu sferze psychoemotywnej.

\footnotetext{
${ }^{26}$ Karol Wojtyła, Człowiek w polu odpowiedzialności (Rzym-Lublin: Ośrodek Dokumentacji Pontyfikatu Fundacji Jana Pawła II, Instytut Jana Pawła II KUL 1991), 26-27.

${ }^{27}$ Tegoż, Elementarz etyczny (Wrocław: TUM, 2000), 30; tegoż, „Natura ludzka jako podstawa formacji etycznej”. Znak 6 (1959): 694.

${ }^{28}$ Woroniecki, Katolicka, t. II/2, 6-7, 71, 153-155.

${ }^{29}$ Tamże, t. I, 262.
} 
Mając świadomość założeń filozoficzno-etycznych, tkwiących u źródeł interpretacji wstydu zaproponowanej przez filozofów, lokujących swoje badania w tradycji zapoczątkowanej przez Tomasza z Akwinu, spróbujmy odpowiedzieć na pytanie, jakie wnioski o charakterze pedagogicznym wynikają z przeprowadzonej $\mathrm{w}$ ramach tradycji neotomistycznej refleksji.

\section{Implikacje pedagogiczne}

Ze sformułowanych w ramach neotomistycznej filozofii wychowania tez wynikają interesujące wnioski zarówno dla teorii pedagogicznej, jak i praktyki wychowawczej.

Po pierwsze, podstawowego czynnika rozwoju moralnego należy upatrywać w samym człowieku, który bez względu na to, jakim oddziaływaniom wychowawczym jest poddawany, sam $\mathrm{w}$ kontakcie $\mathrm{z}$ rzeczywistością, $\mathrm{w}$ ramach jej percepcji i podejmowanych wobec niej decyzji, odkrywa w sobie dwie płaszczyzny: zmysłową i umysłową oraz ich hierarchię, a także implikacje w powinnościach wobec siebie odkrywa, że wartość człowieka jest zachowywana w momencie, gdy podejmuje on rozumne decyzje, a nie pozwala „nieść się” powstającym na poziomie zmysłowym emocjom.

Po drugie, jednym z impulsów do rozwoju moralnego jest wstyd, będący reakcją na działania dające upust czynnikom emocjonalnym i sprzeczne z dążeniem do dobra, wskazanego przez rozum.

Po trzecie, wstyd w pewnym sensie wymaga wsparcia i ochrony, to znaczy potrzebuje punktów odniesienia w postaci prawdy o człowieku oraz o otaczającej go rzeczywistości, innymi słowy wstyd „potrzebuje” kryterium działania wskazanego przez rozum.

Po czwarte, wstyd w rozwoju moralnym odegra właściwą rolę, jeżeli „środowiskiem” dla niego będzie przekonanie o istnieniu prawdy obiektywnej. W klimacie relatywizmu człowiek traci bowiem orientację, co jest dobre, a co złe, uznając niejednokrotnie za dopuszczalne działania polegające na dążeniu do dóbr zmysłowych, mimo tego, że owo dążenie uniemożliwia osiągnięcie dobra rozumnego.

Po piąte, biorąc pod uwagę neotomistyczne tezy, wskazujące na uwarunkowania wstydu, można zauważyć jak na poczucie wstydu, szczególnie w okresie dojrzewania, może wpływać postrzeganie w kulturze norm moralnych jako owocu pewnej umowy o lokalnym zasięgu. $\mathrm{Z}$ takim rozumieniem mamy do czynienia współcześnie w kulturze Zachodu, w której wartości moralne legitymizowane są często za pomocą kompromisu wypracowanego między opozycyjnymi stanowiskami.

Po szóste, bez względu na to, w jakim kontekście kulturowym rozwija się człowiek, w jego naturze znajdują fundamenty, dzięki którym może odkryć, czym jest wewnętrzność, specyfika ludzkiego bytu i jego godność, a w efekcie - budować obiektywistyczny kontekst dla własnej aktywności moralnej (nawet deklarując stanowisko relatywistyczne w zakresie etyki). Przestrzenią tych procesów jest między innymi przeżycie wstydu. 
Po siódme, przedstawiciele neotomistycznej filozofii wychowania analizują znaczenie wstydu dla jakości podejmowanych przez podmiot decyzji (czyli na etapie decydowania, ewentualnie wpływu na kolejne decyzje podejmowane w kontekście wcześniejszych złych decyzji), nie udzielają jednak odpowiedzi na pytanie o sposoby „uwolnienia się" od wstydu w momencie, gdy zło zostało dokonane i nie można go odwrócić, a wstyd staje się destrukcyjny, toksyczny30. Nie odnajdujemy w ich pracach wskazówek, jak poradzić sobie ze wstydem: czy zaniknie wraz z upływem czasu, czy może drogą do jego usunięcia jest na przykład zaakceptowanie własnej przygodności, omylności, słabości i w konsekwencji - przebaczenie sobie.

Po ósme, w tekstach przywołanych w niniejszym opracowaniu nie znajdujemy rozwiązania licznych, bardziej szczegółowych problemów. Można zatem powiedzieć, że dotyczą one jedynie ogólnych zasad. Do kwestii szczegółowych można zaliczyć chociażby problem manipulacji jednostką poprzez wzbudzanie w niej wstydu. I nie chodzi tylko o manipulację konkretną osobą, ale o działania zakrojone na szeroką skalę, prowadzące do wyeliminowania określonych poglądów, stanowisk, a wśród nich także wierzeń religijnych. Innym przykładem problemów szczegółowych, których rozwiązanie wydaje się istotne w kontekście wychowania, jest z pewnością funkcjonowanie wstydu u osób doświadczonych molestowaniem seksualnym czy maltretowaniem ${ }^{31}$.

Podsumowując, należy przyznać, że neotomistyczna filozofia wychowania docenia wartość wstydu w rozwoju moralnym jednostki, przez co stanowi opozycję wobec poglądów uznających wstyd jedynie za czynnik destrukcyjny, od którego należy się uwolnić. Wskazuje też na uwarunkowania wstydu, który może wspierać rozwój moralny człowieka. Równocześnie filozofia neotomistyczna posiada charakter ogólny i nie rozwiązuje szeregu kwestii szczegółowych, ten jednak profil neotomistycznej refleksji o wstydzie związany jest z naturą samej filozofii. Mówiąc zatem o pewnej „słabości” neotomizmu - o problemach nierozwiązanych - należałoby przede wszystkim wspomnieć o „drogach” wychodzenia ze wstydu, który odegrał już swoją rolę i utrwalony może faktycznie wpływać destrukcyjnie na człowieka. Dopowiedzenia w ramach neotomistycznej filozofii wychowania w temacie tutaj podjętym domaga się - moim zdaniem - kwestia akceptacji własnej omylności, słabości moralnej oraz przebaczenia samemu sobie błędów, które już zostały popełnione.

Streszczenie: Wstyd jest przykrym uczuciem, którego człowiek stara się unikać. Mimo to przedstawiciele neotomistycznej filozofii wychowania postrzegają wstyd jako istotny czynnik rozwoju moralnego. Artykuł prezentuje prowadzoną przez przedstawicieli neotomizmu: Jacka Woronieckiego i Karola Wojtyłę, refleksję nad rolą wstydu w rozwoju moralnym. Wstyd jest łączony przez nich z działaniami, w których decydującej roli nie odgrywa rozum, ale rodzące się na

${ }^{30}$ Wstyd destrukcyjny, toksyczny utrwala negatywne myślenie i postawę odrzucenia samego siebie, zaburza kontakt z innymi, może być źródłem kryzysu ,ja” i tożsamości osoby (Błachnio, „Wstyd, 1011-1012).

${ }^{31}$ Lewis, „Emocje”, 791-794. 
poziomie zmysłowym uczucia. Ponieważ zmysły reagują na dobro materialne, a rozum rozpoznaje dobro moralne, dlatego wstyd, który skłania do działań rozumnych, skłania równocześnie do działań uwzględniających dobro moralne. Ponadto wstyd, który ostrzega przed zagrożeniem naruszenia godności człowieka, pomaga odkryć wartość ludzkiego bytu i w ten sposób tworzy fundamenty norm moralnych. Artykuł prezentuje także filozoficzno-etyczne założenia myśli neotomistycznej, które prowadzą do sformułowanej w ramach neotomizmu interpretacji wstydu oraz wnioski wynikające z badań nad wstydem dla teorii pedagogicznej i praktyki wychowawczej.

Słowa kluczowe: wstyd, rozwój moralny, neotomistyczna filozofia wychowania, rozwój działania rozumnego, odkrycie ludzkiej godności

\section{Bibliografia}

Błachnio, Agata. „Wstyd. Aspekt psychologiczny”. W: Encyklopedia katolicka, t. XX, red. Edward Gigilewicz i in., 1011-1012. Lublin: Towarzystwo Naukowe KUL, 2014.

Doliński, Dariusz. „Ekspresja emocji. Emocja podstawowe i pochodne”. W: Psychologia. Podręcznik akademicki, t. 2: Psychologia ogólna, red. Jan Strelau, 351-368. Gdańsk: Gdańskie Wydawnictwo Psychologiczne, 2000.

Drat-Ruszczak, Krystyna. „Teorie osobowości - podejście psychodynamiczne i humanistyczne”. W: Psychologia. Podręcznik akademicki, t. 2: Psychologia ogólna, red. Jan Strelau, 601-652. Gdańsk: Gdańskie Wydawnictwo Psychologiczne, 2000.

Gałkowski, Stanisław. Ku dobru. Aktualność filozofii wychowania Jacka Woronieckiego. Rzeszów: Wydawnictwo Wyższej Szkoły Pedagogicznej, 1998.

Górski, Karol. Wychowanie personalistyczne. Poznań: Naczelny Instytut Akcji Katolickiej, 1936.

Horowski, Jarosław. Wychowanie moralne wedhug pedagogiki neotomistycznej. Torun: Wydawnictwo UMK, 2015.

Kemper, Theodore D. „Modele społeczne w wyjaśnianiu emocji”. Przekład Piotr Kołyszko. W: Psychologia emocji, red. Michael Lewis, Jeannette M. Haviland-Jones, 72-87. Gdańsk: Gdańskie Wydawnictwo Psychologiczne, 2005.

Kostkiewicz, Janina. Kierunki i koncepcje pedagogiki katolickiej w Polsce 1918-1939. Kraków: Oficyna Wydawnicza „Impuls”, 2013.

Lewis, Michael. „Emocje samoświadomościowe: zażenowanie, duma, wstyd, poczucie winy”, przel. Ewa Wojtych, w: Psychologia emocji, red. Michael Lewis, Jeannette M. Haviland-Jones, 780-797. Gdańsk: Gdańskie Wydawnictwo Psychologiczne, 2005.

Mróz, Mirosław. „De verecundia, czyli o kwestii wstydu widzianej oczyma św. Tomasza z Akwinu”, w: Wstyd inagość, red. Marian Grabowski, 177-217. Toruń: Wydawnictwo Uniwersytetu Mikołaja Kopernika, 2003.

Scheler, Max. „O wstydzie i poczuciu wstydu”, przeł. Marzena Świtalska, w: Wstyd i nagość, red. Marian Grabowski, 19-142. Toruń: Wydawnictwo Uniwersytetu Mikołaja Kopernika, 2003.

Tomasz z Akwinu. Suma teologiczna, t. 22: Umiarkowanie. Przekład Stanisław Bełch. Londyn: Katolicki Ośrodek Wydawniczy „Veritas”, 1966.

Wojtyła, Karol. Człowiek w polu odpowiedzialności. Rzym-Lublin: Ośrodek Dokumentacji Pontyfikatu Fundacji Jana Pawła II, Instytut Jana Pawła II KUL, 1991.

Wojtyła, Karol. Elementarz etyczny. Wrocław: TUM, 2000. 
Wojtyła, Karol. Miłość i odpowiedzialność. Lublin: Towarzystwo Naukowe KUL, 1986.

Wojtyła, Karol. „Natura ludzka jako podstawa formacji etycznej”. Znak 6 (1959): 693-697.

Wojtyła, Karol. „Osoba i czyn”. W: tegoż, Osoba i czyn oraz inne studia antropologiczne, 51-344. Lublin: Towarzystwo Naukowe KUL, 1994.

Wojtyła, Karol. „Podmiotowość i «to, co nieredukowalne»”. W: tegoż, Osoba i czyn oraz inne studia antropologiczne, 433-443. Lublin: Towarzystwo Naukowe KUL, 1994.

Wojtyła, Karol. „Transcendencja osoby w czynie a autoteleologia człowieka”. W: tegoż, Osoba i czyn oraz inne studia antropologiczne, 477-490. Lublin: Towarzystwo Naukowe KUL, 1994.

Wojtyła, Karol. „Uczestnictwo czy alienacja?”. W: tegoż, Osoba i czyn oraz inne studia antropologiczne, 445461. Lublin: Towarzystwo Naukowe KUL, 1994.

Woroniecki, Jacek. „Cnota kardynalna umiarkowania”. Szkoła Chrystusowa I/5 (1930): 227-237.

Woroniecki, Jacek. Katolicka etyka wychowawcza, t. I, II/1, II/2. Lublin: Redakcja Wydawnictw KUL, 2000.

Zadykowicz, Tadeusz. „Wstyd. Aspekt moralny”. W: Encyklopedia katolicka, t. XX, red. Edward Gigilewicz i in., 1010-1011. Lublin: Towarzystwo Naukowe KUL, 2014. 